\title{
MOLECULAR PROFLLE OF SENSITIZATION IN SUBJECTS WITH SHORT OCCUPATIONAL EXPOSURE TO LATEX
}

\section{MONICA LAMBERTI ${ }^{1}$, ROSARIA BUONANNO ${ }^{1}$, CHIARA RITONNARO ${ }^{1}$, GIANCARLO GIOVANE ${ }^{1}$, VINCENZO CRISPINO ${ }^{1}$, ANTONIA FEOLA ${ }^{2}$, NICOLA MEDICI ${ }^{2}$, NICOLA SANNOLO ${ }^{1}$, ANGELINA DI CARLO ${ }^{3}$, and MARINA DI DOMENICO ${ }^{2}$}

${ }^{1}$ Second University of Naples, Naples, Italy

Department of Experimental Medicine, Section of Hygiene, Occupational Medicine and Forensic Medicine

${ }^{2}$ Second University of Naples, Naples, Italy

Department of Biochemistry, Biophysics and General Pathology

${ }^{3}$ Sapienza University of Rome, Rome, Italy

Department of Medico-Surgical Sciences and Biotechnologies

\begin{abstract}
Objectives: We examined the prevalence of latex allergy in subjects with occupational exposure to latex allergens for less than 5 years, determining the disease spectrum in symptomatic workers. We identified the most frequent molecular allergens by ImmunoCAP(ICAP), correlating the findings with skin prick test (SPT) results. Material and Methods: Seven hundred twenty-three healthcare students using latex gloves on a regular basis were invited to participate in a baseline questionnaire screening. An ICAP serum test was performed only when a possible latex allergy was indicated by the questionnaire. Results: The total number of participants responding to the baseline survey was 619 . Glove-related symptoms were indicated by $4 \%(\mathrm{~N}=25)$ of the students. The most common symptom was contact dermatitis $(\mathrm{N}=18,72 \%)$. In 12 subjects, ICAP revealed a real sensitization to latex, with a recombinant latex allergen profile showing a high frequency for $\mathrm{rHev} b 6.01$ specific immunoglobulin $\mathrm{E}(\mathrm{sIgE})(\mathrm{N}=9,67 \%)$. In these individuals, skin symptoms were more prevalent than other types (88\%). Conclusions: The combined positivity for rHev b 6.01, rHev 8 and rHev b 5 determined by ICAP identified $92 \%$ of latex-allergic subjects with short-term exposure to latex.
\end{abstract}

Key words:

Occupational exposure, ImmunoCAP, Natural rubber latex, Skin prick test, Contact dermatitis, Gloves

\section{INTRODUCTION}

Natural rubber latex (NRL) comes from the sap of the tropical tree Hevea brasiliensis. It is an elastic agent (polymeric cis-1,4 isoprene) with a proteic component of 2-3\%. More precisely, 15 latex proteins have been identified and characterized [1]. Sometimes it is very difficult to discern between NRL allergy and an asymptomatic state of awareness, on account of the presence of carbohydrate cross-reacting determinants or profilin. In fact, many cases of sensitization to latex profilin occurs via profilins of pollen or food origin [2-5].

Allergy to NRL has been an important occupational health concern for more than 20 years, particularly among healthcare workers, because about $50 \%$ of medical

Received: August 4, 2014. Accepted: December 18, 2014.

Corresponding author: M. Lamberti, Second University of Naples, Department of Experimental Medicine, Section of Hygiene, Occupational Medicine and Forensic Medicine, School of Medicine, Viale dei Crecchi 16, 80100 Naples, Italy (e-mail: monicalamberti@libero.it). 
devices contain latex. The main source of workplace exposure is use of powdered latex gloves by healthcare workers. In studies on hospital personnel, latex sensitivity was found to be 3-5 times higher among nurses and doctors than among personnel not involved in patient care [6-21]. The prevalence of latex allergy in healthcare settings is reported to be affected by several factors, including atopy [21-23], frequency of glove use, prior or current hand dermatitis and also the long exposure-times when working in hospitals [24-27].

The objectives of this study were:

- to examine the prevalence of latex allergy in a group of 723 subjects with less than 5 years of occupational exposure to latex;

- to determine the disease spectrum in symptomatic workers who met the inclusion criteria;

- to identify the most frequent molecular allergens for the diagnosis of genuine latex allergy in this symptomatic group by ImmunoCAP (ICAP) and to correlate these results with skin prick tests (SPT).

In fact, ICAP is becoming a viable alternative to other in vivo tests because it has increased diagnostic accuracy for latex allergy and can be used in those subjects who have special medical conditions (e.g., extended dermatitis, urticaria in the active phase, cutaneous anergy, recent intake of interfering medication such as antihistamines) that contraindicate the conduction of skin tests $[26,27]$.

\section{MATERIAL AND METHODS}

Seven hundred twenty-three subjects attending their 2-yearly occupational health visit according to legislative decree 81 [28] (i.e., year 3 and 6 medical students, and year 1 and 3 nursing students) and having had occupational exposure to latex for less than 5 years through the regular use of latex gloves (i.e., at least once or twice a week) were invited to participate in a baseline screening in accordance with the guidelines for health monitoring established by the occupational physician. We obtained informed consent from each subject to perform the examination and to publish the final results [29]. Exclusion criteria were treatment with $\beta$-blockers, antihistamines, tricyclic antidepressants or corticosteroids up to 3 weeks before the study, and pregnancy or breast feeding [30]. The 2 types of gloves distributed and equally used at the university's hospital are powdered latex gloves (Naturex 626 Classic, Nacatur, Italy) and non-powdered latex gloves (Naturex 626 Salus, Nacatur, Italy).

The questionnaire was given by 4 trained interviewers. Sociodemographic data were checked to characterize the study population and to investigate risk factors, and clinical symptoms were recorded. Questions included sex, age, frequency of latex glove use, exposure (hours of glove use per day up to 3 days before the interview) and information on family and personal histories of allergic disorders, exposure to other latex items (household cleaning gloves, balloons, diaphragm, condoms), number of times a day that hands were washed, and exposure to chemical irritants at work. We also asked about smoking and medical history [31,32].

Contact urticaria related to latex use was defined as a selfreported weal and flare reaction at the site of glove contact, appearing within 10-15 min of usage. Generalized urticaria was defined as a self-reported weal and flare reaction appearing at several skin sites. Contact dermatitis was defined as a self-reported persistent erythemato-papulous eruption appearing on the skin after 2-3 days from contact with latex gloves [33]. Eye and respiratory symptoms (burning, stuffy sensations, sneezing or asthmatic symptoms) were deemed present if 1 or more symptoms were reported at least a few days a week [33].

Only when the questionnaire indicated a possible allergy to latex was an SPT performed with disposable sterile needles on the volar region of the forearm. A commercial latex preparation at a concentration of $100 \mathrm{IR} / \mathrm{ml}$ (Stallergenes Italia, Milan, Italy) was used as the allergen. Histamine $(10 \mathrm{mg} / \mathrm{ml})$ was used as a positive control; a sterile 
saline solution $(0.95 \% \mathrm{NaCl})$ was used as a negative control. The test was considered positive if after $15 \mathrm{~min}$ wheal size exceeded $3 \mathrm{~mm}$ [31].

Serum obtained from subjects was tested using the ImmunoCAP ${ }^{\circledR} 250$ system (fluorescence enzyme immunoassay - FEIA) in accordance with the manufacturer's instructions (Phadia, Uppsala, Sweden). All sera were analysed for specific IgE against an NRL extract supplemented with rHev b 5 (Phadia Latex Recombi+k82 ImmunoCAP $^{\circledR}$, range from $0.1100 \mathrm{kU} / \mathrm{l}$ to $\left.>100 \mathrm{kU} / \mathrm{l}\right), 9$ Escherichia coli recombinant latex allergens ( $\mathrm{rHev} b 1$, rHev b 2, rHev b 3, rHev b 5, rHev b 6.01, rHev b 6.02, rHev b 8, rHev b 9, rHev b 11 ImmunoCAP $\left.^{\circledR}\right)$. Specific immunoglobulin $\mathrm{E}$ ( $\mathrm{sIgE}$ ) values $>0.10 \mathrm{kU} / \mathrm{l}$ were considered positive [34]. ImmunoCAPs ${ }^{\text {тM }}$ containing HRP (Ro400) and bromelain ( $\mathrm{k} 202)$ were chosen to detect cross-reactive carbohydrate determinants specific (CCD-specific) IgE. All recombinant latex allergens offered in the ImmunoCAP platform, except $\mathrm{rHev}$ b 5, are produced as maltose-binding protein (MBP) fusion proteins. For this reason, MBP was coupled to a separate ImmunoCAP ${ }^{\mathrm{TM}}$ to serve as a control [35].

\section{RESULTS}

The total number of participants responding to the baseline survey was 619, representing a participation rate of $85.6 \%$. A group of 104 (14.4\%) subjects refused to complete the questionnaire: because completion was recommended but not mandatory, part of the subjects wished to reduce the duration of the medical examination by preferring not to fill it out.

The study population had a mean age of $22.5 \pm 2.6$ years and an average work seniority of $2.5 \pm 2.4$ years. There were more women $(\mathrm{N}=411,66.4 \%)$ than men $(\mathrm{N}=208,33.6 \%)$, and a prevalence of medical ( $\mathrm{N}=397,64 \%)$ over nursing $(\mathrm{N}=222,36 \%)$ students. Glove-related symptoms were present in 25 (4\%) students, 19 of whom were women and 6 were men. In subjects in whom the questionnaire indicated a possible allergy to latex, the most common symptoms were contact dermatitis $(\mathrm{N}=18,72 \%)$, contact urticaria $(\mathrm{N}=3,12 \%)$, generalized urticaria $(\mathrm{N}=1,4 \%)$, rhinitis $(\mathrm{N}=6 ; 24 \%)$ and asthma $(\mathrm{N}=4,16 \%)$. Some subjects had more than 1 symptom.

In $5(20 \%)$ of 25 subjects, neither ICAP nor SPT revealed sensitization to latex. In this group, symptoms reported in the questionnaire were predominantly of the eye and respiratory type $(\mathrm{N}=4,80 \%)$. In the other 20 subjects, 18 (90\%) were positive upon SPT, whereas $12(60 \%)$ were found with $\operatorname{sgE}$ against recombinant latex allergens (ImmunoCAP k82: 1.1-17.9 kU/l). In 12 subjects, the highest prevalence was observed for $\mathrm{rHev} b 6.01 \operatorname{sigE}(\mathrm{N}=9,67 \%)$, followed by rHev b $8(\mathrm{~N}=7,58 \%)$ and rHev b $5(\mathrm{~N}=5,42 \%)$ (Figure 1). The widest range was found for $\mathrm{rHev} b 6.01 \mathrm{sIgE}$ (0.1-7.7 kU/l) (Figure 2). The ImmunoCAP k82 values were higher in subjects positive to $\mathrm{rHev}$ b $6.01 \mathrm{sIgE}$ $(99.9 \mathrm{kU} / \mathrm{l})$. The highest average of ImmunoCAP k82 value was for $\mathrm{rHev}$ b $2(13.7 \mathrm{kU} / \mathrm{l})$. Only $2 / 12$ subjects showed a mono-sensitization, both to rHev b 5; while the remaining 10/12 had multiple sensitization. The 2 monosensitized subjects were SPT-negative. We found a strong correlation between latex SPT positivity and rHev b 6.01 reactivity: considering only the 18 patients found positive upon SPT, the highest prevalence

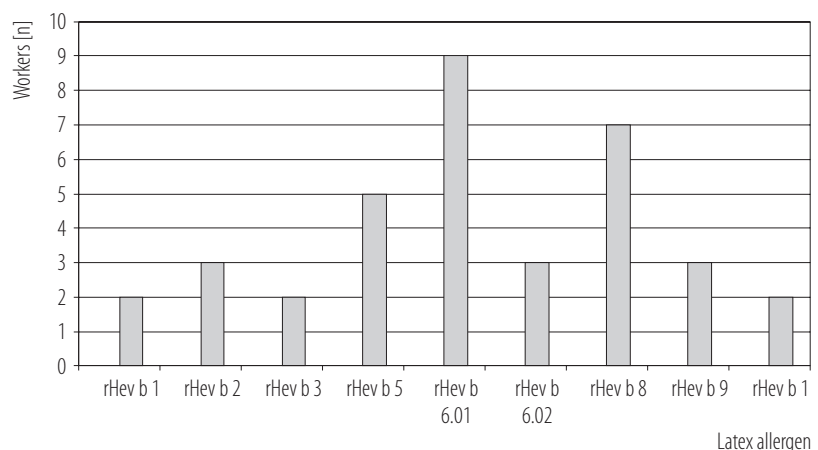

Fig. 1. Prevalence of specific immunoglobulin E (sIgE) to recombinant latex allergens with values $\geq 0.10 \mathrm{kU} / \mathrm{l}$ in the allergic workers 


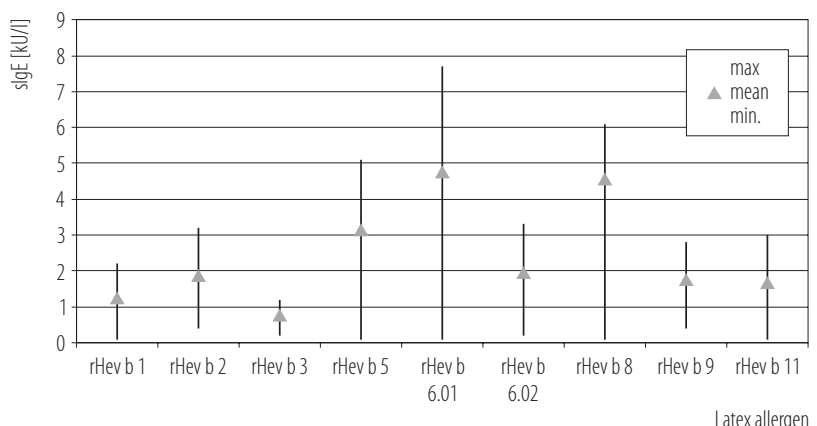

Max - maximal value; min. - minimal value.

Fig. 2. Specific immunoglobulin E (sIgE) to recombinant latex allergens in the allergic population

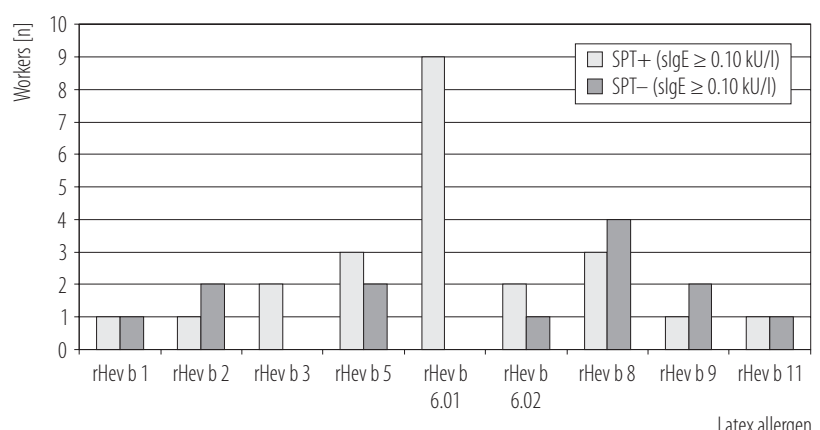

Fig. 3. Skin prick test positive (SPT+) and negative (SPT-) with specific immunoglobulin $\mathrm{E}(\mathrm{sIgE}) \geq 0.10 \mathrm{kU} / \mathrm{l}$

was observed for rHev b $6.01 \mathrm{sIgE}(\mathrm{N}=9,50 \%)$, besides the best correlation between SPT positivity and the single allergens was found for $\mathrm{rHev}$ b $3(\mathrm{~N}=2 / 2)$ and rHev b $6.01 \mathrm{sIgE}(\mathrm{N}=9 / 9)$. Instead, only $33 \%$ of patients with values greater than $0.10 \mathrm{kU} / \mathrm{l}$ for rHev b $2(\mathrm{~N}=1 / 3)$ and for rHev b $9(\mathrm{~N}=1 / 3)$ were found positive upon SPT (Figure 3).

The percentage of concentration of different $\operatorname{sIgE}$ to recombinant latex allergens in all 12 ImmunoCAP positive subjects is shown in Figure 4. The highest correlation between symptoms and type of $\operatorname{sigE}$ was found for rHev b $6.01 \mathrm{sIgE}$ and contact dermatitis $(\mathrm{N}=7 / 18,44 \%)$. We did not find specific IgE response to the 2 CCD-reagents (HRP and bromelain) in any of the subjects.

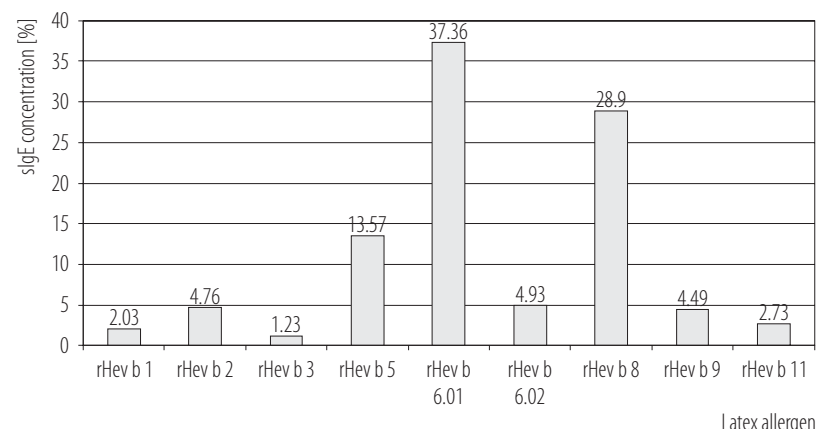

Fig. 4. Concentration of specific immunoglobulin E (sIgE) to recombinant latex allergens

\section{DISCUSSION}

Natural rubber latex is a cytoplasmic exudate of the lacticifer layer of trees and contains most of the cytosolic organelles and proteins found in any plant cell. However, chemical treatment (hydrolysis) and the addition of substances such as ammonium hydroxide, thiurams or carbamates cause that users are exposed to a complex mixture of residual chemicals and the hydrolyzed latex peptides that seem to be involved in type 1 allergic reactions [36,37].

Gloves made from NRL have been in use since the 19th century as a means of protecting patients and healthcare workers from contracting infectious diseases; the use of latex gloves has increased more than tenfold over the last 30 years [38]. However, the international scientific community has paid attention to allergic-type reactions to NRL only since the beginning of the 1980s, despite the fact that reference to this problem started appearing over 65 years ago [39-41]. The use of latex gloves is a well-known occupational problem for healthcare workers, and has been identified as a major source of occupation-related skin and respiratory allergies in these workers. As noted above, the prevalence of latex allergy in healthcare workers varies considerably, from 2-9\% in Finland [25] to 4-7\% in Belgium among hospital employees [12], and from $7 \%$ in operating room staff in Finland [25] to $9-10 \%$ among operating room nurses in 
France [11] and surgeons, anaesthesiologists and radiologists in Canada [9].

As far as we know, the present study is the 1st cross-sectional survey of latex sensitivity among subjects with an occupational exposure to latex of less than 5 years. Symptoms related to latex-glove use were indicated in $4 \%$ of questionnaires and confirmed in $1.9 \%$ by ICAP. This relatively low percentage could be related to the low mean age and work seniority of our study group. In fact, absorption of latex proteins through the skin is considered by some authors to be the main pathway of sensitization, and this event can be associated with long-term latex exposure [22-25].

In the 25 subjects that indicated a possible allergy to latex in the questionnaire, the incidence of cutaneous symptoms was $88 \%$, with contact dermatitis present alone in $72 \%$. In the 5 subjects positive according to the questionnaire but negative with SPT and ICAP, symptoms were mainly of a non-cutaneous type and, therefore, likely to be caused by sensitization to other allergens, such as pollen and food.

In recent years, the direct determination of specific IgEs to allergen subgroups has become very important [30]. Among the 15 molecularly characterized NRL Hev b allergens, Hev b 5 and b 6 seem to play a major role in sensitizing healthcare workers $[30,42]$ and patients with respiratory symptoms [43]. Moreover, spina bifida patients typically show sensitization to Hev b 1 and b 3, but also to Hev b 5, b 6 [44] and b 7 [45], even if to a lesser extent. Hev b 8 is a profilin involved in latex-fruit syndrome $[2,46]$. Hev b 9, an enolase [47], was described in cases of latex sensitization in healthcare workers but not in spina bifida patients [48]. In particular, Yagami et al. [30] found in 20 healthcare workers suspected of having latex allergy that the positive ratios of serum-specific IgE for latex, rHev b 6.01 and rHev b 6.02 were all $100 \%$, while those for $\mathrm{rHev}$ b 5, rHev b 8 and $\mathrm{rHev}$ b 11 were $42.8 \%, 14.2 \%$ and $7.1 \%$, respectively.
Rihs et al. [49] reported that the IgE-binding prevalence of the allergens in healthcare workers was $52 \%$ for rHev b 1 and 13-20\% for rHev b 3, whereas the prevalence for rHev b 6.02 was $75 \%$. In our study, ICAP confirmed the result of the SPT in 10/18 (55\%) of subjects. The most relevant allergens in those found positive by SPT were rHev b 6.01, rHev 8 and rHev b 5 (Figure 3). The combination of these 3 allergens identified $92 \%$ of the latex-allergic subjects in our series. It is important to remember that a high percentage of positivity to $\mathrm{rHev} 8$ could be attributed to latex-fruit syndrome. However, in accordance with previous studies [50,51], Hev b 8 monosensitized persons did not present with latex-specific symptoms upon contact with latex-containing material, whereas in our study rHev 8 positivity was always associated with positivity to rHev b 6.01 and rHev b 5 .

Reactivity to HRP and bromelain was proved to be an in vitro-effective screening tool for differentiating true latex allergy from clinically insignificant elevated specific $\mathrm{IgE}$ to NRL [35].

In our study, however, we have not found specific IgE response to the 2 CCD-reagents in all allergic subjects. These data were probably due to the low number of patients sensitized to rHev b 2 (3/18), the allergen mainly involved in cross-reactive carbohydrate determinants [51]. Another finding that should be emphasized is the higher prevalence of mono-sensitization to rHev b 5 in SPT-negative subjects. This finding, although limited by the low number of these subjects in our study $(\mathrm{N}=2)$, is nonetheless in agreement with previous literature [34].

\section{CONCLUSIONS}

Through the use of a questionnaire, our study has highlighted a prevalence of latex allergy in $4 \%$ of healthcare students exposed to latex for less than 5 years; this is a lower incidence than that reported in the literature for healthcare workers $[9,11,12,25]$. The ICAP showed rubber latex allergy profile with a high frequency of $\mathrm{rHev}$ b 6.01, 
rHev b 5 and rHev b 8 sIgEs among subject with occupational exposure to latex for less than 5 years. Furthermore, ICAP is also an economical method and one safer than in vivo tests, which are encumbered with a risk of possible adverse reactions, such as anaphylactic shock [34]. Thus, it is a reliable tool for the occupational physician because it determines the amount of the immunogenic potential of each molecular component to which the subject is positive and then predicts the risk of the worker to develop clinical events [39].

\section{REFERENCES}

1. International Union of Immunological Societies Allergen Nomenclature Sub-Committee [Internet]. Allergen nomenclature: Hevea brasiliensis [cited 2014 Sep 25]. Available from: http://www.allergen.org/search.php?allergenname $\% 20=$ $\%$ 20\&allergensource $\% 20=\% 20$ Hevea + brasiliensis $\&$ Tax Source $\% 20=\% 20 \&$ TaxOrder $\% 20=\% 20 \&$ foodallerg $\% 20$ $=\% 20$ all $\&$ bioname $\% 20=$.

2. Ganglberger E, Rauder C, Wagner S, O'Riordain GO, Beezhold DH, Brehler R. Hev b 8, the Hevea brasiliensis latex profilin is a cross-reactive allergen of latex plant, food and pollen. Int Arch Allergy Immunol. 2001;125:216-27, http://dx.doi.org/10.1159/000053819.

3. Schuler S, Ferrari G, Schmid-Grendelmeier P, Harr T. Microarray-based component-resolved diagnosis of latex allergy: Isolated IgE-mediated sensitization to latexprofilin Hev b8 may act as confounder. Clin Transl Allergy. 2013;3:11-3, http://dx.doi.org/10.1186/2045-7022-3-11.

4. Ebo DG, Hagendorens MM, Bridts CH, de Clerck LS, Stevens WJ. Sensitization to cross-reactive carbohydrate determinants and the ubiquitous protein profilin: Mimickers of allergy. Clin Exp Allergy. 2004;34:137-44, http://dx.doi. org/10.1111/j.1365-2222.2004.01837.x.

5. Antonicelli L, Micucci C, Mistrello G, Roncarolo D, Zanotta S, Cinti B, et al. Improving latex-allergy diagnosis: The clinical role of Hev b8-specific IgE. Allergy. 2008;63:620-1, http:// dx.doi.org/10.1111/j.1398-9995.2008.01651.x.
6. Allmers H, Schmengler J, John SM. Decreasing incidence of occupational contact urticaria caused by natural rubber latex allergy in German health care workers. J Allergy Clin Immunol. 2004;114:347-51, http://dx.doi.org/10.1016/ j.jaci.2004.05.054.

7. Charous BL, Blanco C, Tarlo S, Hamilton RG, Baur X, Beezhold D, et al. Natural rubber latex allergy after 12 years: Recommendations and perspectives. J Allergy Clin Immunol. 2002;109:31-4, http://dx.doi.org/10.1067/ mai.2002.120953.

8. Frew AJ. Advances in environmental and occupational disorders. J Allergy Clin Immunol. 2003;111:824-8, http:// dx.doi.org/10.1067/mai.2003.151.

9. Arellano R, Bradley J, Sussman GL. Prevalence of latex sensitization among hospital physicians occupationally exposed to latex gloves. Anesthesiology. 1992;77:905-7.

10. Fiorito A, Larese F, Molinari S, Negro C, Barbina P, Peresson M. Allergic sensitization and latex-associated symptoms in a group of health workers. Med Lav. 1996;87(5):423-31.

11. Lagier F, Vervloet D, Lhermet I, Poyen D, Charpin D. Prevalence of latex allergy in operating room nurses. J Allergy Clin Immunol. 1992;90:319-24, http://dx.doi.org/10.1016/ S0091-6749(05)80009-0.

12. Vandenplas O, Delwiche JP, Evrard G, Aimon P, van der Brempt X, Jamart J, et al. Prevalence of occupational asthma due to latex among hospital personnel. Am J Respir Crit Care Med. 1995;151:54-60, http://dx.doi.org/ 10.1164/ajrccm.151.1.7812572.

13. Yassin MS, Lierl MB, Fischer TJ. Latex allergy in hospital employees. Ann Allergy. 1994;72:245-9.

14. Slater JE, Mostello LA, Shaer C. Rubber-specific IgE in children. J Urol. 1991;146:578-81.

15. Hunt LW, Fransway AF, Reed CE. An epidemic of occupational allergy to latex involving health care workers. J Occup Environ Med. 1995;37:1204-7, http://dx.doi. org/10.1097/00043764-199510000-00011.

16. Geier J, Lessmann H, Mahler V, Pohrt U, Uter W, Schnuch A. Occupational contact allergy caused by rubber gloves - 
Nothing has changed. Contact Dermatitis. 2012;67: 149-56, http://dx.doi.org/10.1111/j.1600-0536.2012.02139.x.

17. Amarasekera M, Rathnamalala N, Samaraweera S, Jinadasa M. Prevalence of latex allergy among healthcare workers. Int J Occup Med Environ Health. 2010;23:391-6, http:// dx.doi.org/10.2478/v10001-010-0040-5.

18. Chaari N, Sakly A, Amri C, Mahfoudh A, Henchi MA, Khalfallh $\mathrm{T}$, et al. Occupational allergy in healthcare workers. Recent Pat Inflamm Allergy Drug Discov. 2010;4:65-74, http://dx.doi.org/10.2174/187221310789895630.

19. Turijamaa K. Incidence of immediate allergy to latex gloves in hospital personnel. Contact Dermatitis. 1987;17:270-5, http://dx.doi.org/10.1111/j.1600-0536.1987.tb01476.x.

20. Hadjiliadis D, Khan K, Tarlo SM. Prevalence of skin test latex sensitivity in an allergy/asthma population. J Allergy Clin Immunol. 1995;96:431-2.

21. Watts DN, Jacobs R, Forrester B, Bartolucci A. An evaluation of the prevalence of latex sensitivity among atopic and non atopic intensive care workers. Am J Ind Med. 1998;34:359-63, http://dx.doi.org/10.1002/(SICI)1097-0274 (199810)34:4 > 359::AID-AJIM9 > 3.0.CO;2-N.

22. Hamann CP. Natural rubber latex protein sensitivity in review. Am J Contact Dermat. 1993;4:4-21, http://dx.doi.org/ 10.1097/01634989-199303000-00003.

23. Kibby T, Akl M. Prevalence of latex sensitization in a hospital employee population. Ann Allergy Asthma Immunol. 1997;78:41-4, http://dx.doi.org/10.1016/S1081-1206 (10)63370-4.

24. Konrad C, Fieber T, Gerber H. The prevalence of latex sensitivity among anesthesiology staff. Anesth Analg. 1997;84:629-33.

25. Turjanmaa K, Reunala T, Rasanen L. Comparison of diagnostic methods in latex surgical glove contact urticaria. Contact Dermatitis. 1988;19:241-7, http://dx.doi. org/10.1111/j.1600-0536.1988.tb02920.x.

26. Cox L. Overview of serological-specific IgE antibody testing in children. Curr Allergy Asthma Rep. 2011;11:447-53, http://dx.doi.org/10.1007/s11882-011-0226-3.
27. Hamilton RG. Proficiency survey-based evaluation of clinical total and allergen-specific IgE assay performance. Arch Pathol Lab Med. 2010;134:975-82.

28. Buss ZS, Fröde TS. Latex allergen sensitization and risk factors due to glove use by health care workers at public health units in Florianopolis, Brazil. J Investig Allergol Clin Immunol. 2007;17:27-33.

29. [Italian Law decree No. 9/4/2008, n. 81. Consolidated law on health and safety at work]. Available from: http:// www.lavoro.gov.it/SicurezzaLavoro/Documents/TU\%20 81-08\%20-\%20Ed.\%20Ottobre\%202013.pdf. Italian.

30. Yagami A, Suzuki K, Saito H, Matsunaga K. Hev B 6.02 is the most important allergen in health care workers sensitized occupationally by natural rubber latex gloves. Allergol Int. 2009 Sep;58(3):347-55, http://dx.doi.org/10.2332/ allergolint.08-OA-0046.

31. Buss ZS, Kupek E, Fröde TS. Screening for latex sensitization by questionnaire: Diagnostic performance in health care workers. J Investig Allergol Clin Immunol. 2008;18:12-6.

32. Larese F, Negro C, Barbina P. Latex risk: Our experience using targeted questionnaire in Trieste hospital. Folia Med. 1996;67:283-9.

33. Filon FL, Radman G. Latex allergy: A follow up study of 1040 healthcare workers. Occup Environ Med. 2006;63: 121-5, http://dx.doi.org/10.1136/oem.2003.011460.

34. Garnier L, Selman L, Rouzaire P, Bouvier M, Roberts O, Bérard F, et al. Molecular allergens in the diagnosis of latex allergy. Eur Ann Allergy Clin Immunol. 2012;44:73-9.

35. Raulf-Heimsoth M, Rihs HP, Rozynek P, Cremer R, Gaspar A, Pires G, et al. Quantitative analysis of immunoglobulin $\mathrm{E}$ reactivity profiles in patients allergic or sensitized to natural rubber latex (Hevea brasiliensis). Clin Exp Allergy. 2007;37:1657-67, http://dx.doi.org/10.1111/j.13652222.2007.02833.x.

36. Ebo DG, Stevens WJ, Bridts CH, de Clerck LS. Latexspecific IgE, skin testing, and lymphocyte transformation to latex in latex allergy. J Allergy Clin Immunol. 1997;100: 618-23, http://dx.doi.org/10.1016/S0091-6749(97)70165-9. 
37. Cullinan P, Brown R, Field A, Hourihanes J, Jones M, Kekwick R, et al. Latex allergy. A position paper of the British Society of Allergy and Clinical Immunology. Clin Exp Allergy. 2003;33:1484-99, http://dx.doi.org/10.1046/j.13652222.2003.01818.x.

38. Mota ANB, Turrini RNT. Perioperative latex hypersensitivity reactions: An integrative review. Rev Lat Am Enfermagem. 2012;20:411-20, http://dx.doi.org/10.1590/S010411692012000200026.

39. Cabanes N, Ilgea JM, de la Hoz B. Latex allergy: Position paper. J Investig Allergol Clin Immunol. 2012;22:313-30.

40. Allmers H, Schmengler J, John SM. Decreasing incidence of occupational contact urticaria caused by natural rubber latex allergy in German health care workers. J Allergy Clin Immunol. 2004;114:347-51, http://dx.doi.org/10.1016/ j.jaci.2004.05.054.

41. Charous BL, Blanco C, Tarlo S, Hamilton RG, Baur X, Beezhold D, et al. Natural rubber latex allergy after 12 years: Recommendations and perspectives. J Allergy Clin Immunol. 2002;109:31-4, http://dx.doi.org/10.1067/ mai.2002.120953.

42. Kurup VP, Sussman GL, Yeang HY, Elms N, Breiteneder H, Arif SA, et al. Specific IgE response to purified and recombinant allergens in latex allergy. Clin Mol Allergy. 2005;3:11, http://dx.doi.org/10.1186/1476-7961-3-11.

43. Mari A, Scala E, D’Ambrosio C, Breiteneder H, Wagner S. Latex allergy within a cohort of not-at-risk subjects with respiratory symptoms: Prevalence of latex sensitization and assessment of diagnostic tools. Int Arch Allergy Immunol. 2007;143(2):135-43, http://dx.doi.org/ 10.1159/000099080.

44. Pamies R, Oliver F, Raulf-Heimsoth M, Rihs HP, Barber D, Boquete $\mathrm{M}$, et al. Patterns of latex allergen recognition in children sensitized to natural rubber latex. Pediatr Allergy
Immunol. 2006;17(1):55-9, http://dx.doi.org/10.1111/j.13993038.2005.00341.x.

45. Wagner B, Buck D, Hafner C, Sowka S, Niggemann B, Scheiner O, et al. Hev b 7 is a Hevea brasiliensis protein associated with latex allergy in children with spina bifida. J Allergy Clin Immunol. 2001;108(4):621-7, http://dx.doi. org/10.1067/mai.2001.118289.

46. Ganglberger E, Radauer C, Wagner S, Riordain G, Beezhold DH, Brehler R, et al. Hev b 8, the Hevea brasiliensis latex profilin, is a cross-reactive allergen of latex, plant foods and pollen. Int Arch Allergy Immunol. 2001;125: 216-27, http://dx.doi.org/10.1159/000053819.

47. Wagner S, Breiteneder H, Simon-Nobbe B, Susani M, Krebitz M, Niggemann B, et al. Hev b 9, an enolase and a new cross-reactive allergen from Hevea latex and molds. Purification, characterization, cloning and expression. Eur J Biochem. 2000;267(24):7006-14, http://dx.doi.org/10.1046/ j.1432-1327.2000.01801.x.

48. Raulf-Heimsoth M, Rihs HP, Rozynek P, Cremer R, Gaspar A, Pires G, et al. Quantitative analysis of immunoglobulin $\mathrm{E}$ reactivity profiles in patients allergic or sensitized to natural rubber latex. Clin Exp Allergy. 2007;37(11): 1657-67.

49. Rihs H-P, Raulf-Heimsoth M. Natural rubber latex allergens: Characterization and evaluation of their allergenic capacity. 3th ed. Uppsala: Pharmacia Diagnostics AB; 2003.

50. Antonicelli L, Micucci C, Mistrello G, Roncarolo D, Zanotta S, Cinti B, et al. Improving latex-allergy diagnosis: The clinical role of Hev b8-specific IgE. Allergy. 2008;63: 620-1, http://dx.doi.org/10.1111/j.1398-9995.2008.01651.x.

51. Raulf-Heimsoth M, Jappe U, Yeang HY, Arif SAM, Rihs HP, Lopata AL, et al. Relevance of carbohydrate determinants in differentiating true latex allergy from asymptomatic IgE reactivity. Allergy Clin Immunol Int. 2007;2:1-3.

This work is available in Open Access model and licensed under a Creative Commons Attribution-NonCommercial 3.0 Poland License - http://creativecommons.org/ licenses/by-nc/3.0/pl/deed.en. 